\title{
Stephen Jay Gould and Karl Popper on Science and Religion
}

\author{
AMERIGO BARZAGHI \\ Universitat Internacional de Catalunya, Barcelona \\ ambarzaghi@uic.es

\section{JOSEP CORCÓ} \\ Universitat Internacional de Catalunya, Barcelona \\ jcorco@uic.es
}

\begin{abstract}
This paper analyzes the thought on science and religion of two thinkers that share essentially the same position: Stephen Jay Gould and Karl Popper. We first make a comparison between those passages of their works where this similarity emerges more explicitly. We then recall some of the critiques that have been extended to Gould on this topic; they can be extended to Popper as well. Moreover, we highlight another critical issue - taken from evolutionary theory - that Gould's theorization is not able to handle adequately from the theological standpoint. We finally place Gould's proposal inside Barbour's fourfold typology for the science-religion relationship, and we conclude by recommending further critical reflection on these interdisciplinary issues.
\end{abstract}

Keywords: Stephen Jay Gould; Karl Popper; science and religion; non-overlapping magisteria; independence; dialogue. 


\section{Introduction}

According to Ian Barbour, the different ways in which the relation between science and religion is usually conceived can be categorized by means of a fourfold typology: conflict, independence, dialogue, and integration (Barbour 1998, 77-105). The debate on this topic is nowadays very complex and rich, and various epistemological frameworks have been put forth to modify or revise the one originally proposed by Barbour (see for instance Peters 1998; Stenmark 2004b; Murray 2009). For present purposes, we will nonetheless refer to these four options. The aim of this paper is, first of all, to make an introductory comparison of the ideas on science and religion of two very well-known thinkers. The first one, Stephen Jay Gould (†2002), was a famous paleontologist and an incredibly prolific popularizer. The second, Karl Popper († 1994), has been one of the most important philosophers of science of the twentieth century. These two authors have elaborated an essentially equivalent position on this topic, the latter almost sixty years before the former. Indeed, both agree in criticizing the first option-the conflict thesis-and maintain that science and religion are independent enterprises. This commonality is significant, and is worth investigating in more detail.

Karl Popper dealt with the relationship between science and religion on the occasion of a lecture entitled "Science and Religion", held in New Zealand in the year 1940; the broader context was a "discussion course" on "Religion: Some Modern Problems and Developments". This essay can be found in the Popper Archive at the Hoover Institution, cyclostyled and with handwritten revisions by the author which concern only the style and not the content (Popper 2008, 432-433). It remained unpublished for many years, to finally appear in the collection After the Open Society: Selected Social and Political Writings. In this book, it is followed by an interview with Edward Zerin that dates back to 1969, and that was published after his death, in 1998 (Popper 2008, 48-52). On the other hand-almost sixty years later but nine years before the publication of Popper's aforementioned essay-Stephen Jay Gould published a short book on the same topic, named Rocks of Ages: Science 
and Religion in the Fullness of Life (2002 [1999]). After a brief comparison of these two works, we will shortly recall some of the critiques that have been extended to Gould on this topic. These critiques, because of the similarities between the two proposals, can be extended to Popper as well. A second aim of this work is to further foster critical reflection on interdisciplinary issues, moving from these two authors' viewpoint.

In this context, the thought of the Spanish philosopher of science and science and religion scholar Mariano Artigas († 2006) intersects with both these authors. Indeed, he devoted a considerable part of his career as a philosopher of science to an in-depth study and clarification of Popper's philosophical proposal (Artigas 1979; 1998; 1999; 2002). Furthermore, as a scholar of science and religion, he tackled the view of Stephen Jay Gould on this topic in a paper written in Spanish (Artigas 2005). Moreover, chapter two of his Oracles of Science: Celebrity Scientists versus God and Religion-co-authored with Karl Giberson-is dedicated to Gould, and its last section deals with Gould's thought on science and religion (Giberson and Artigas 2007, 79-85). Therefore, on the occasion of the tenth anniversary of Artigas's death, this paper offers a comparison, and a short analysis, of a specific aspect of the thought of two important authors that inhabited his intellectual landscape.

\section{A Brief Comparison}

In analyzing the two works under scrutiny, it can be clearly recognized that both Gould and Popper agree in thinking that there is no intrinsic and inevitable conflict between science and religion. The fundamental concern in articulating their position is to show that conflicts originated and originate when, whether moving from the scientific or the religious area, trespasses occur. If scientists go beyond the description and explication of the natural world, and reason about how human beings should behave by referring to their science, they trespass beyond their own area of expertise. If, on the other hand, religious people try to explain factual things, whose explication pertains to science, by referring to their own religious beliefs, they too 
trespass beyond their borders (Popper 2008, 41). In a concise passage at the beginning of his book, Gould offers a brief description of both science and religion: "Science tries to document the factual character of the natural world, and to develop theories that coordinate and explain these facts. Religion, on the other hand, operates in the equally important, but utterly different, realm of human purposes, meanings, and values" (Gould 2002, 4). Gould famously labels the two different areas of science and religion "magisteria". And, in affirming that the two don't overlap, he introduces the acronym NOMA-Non-Overlapping Magisteria (Gould 2002, 5) ${ }^{1}$. The two domains have different methodologies, and different purposes: "Each domain of inquiry frames its own rules and admissible questions, and sets its own criteria for judgement and resolution. These accepted standards, and the procedures developed for debating and resolving legitimate issues, define the magisterium - or teaching authority - of any given realm” (Gould 2002, 52-53). Science and religion are then-from this point of view-distinguished both logically and methodologically (Gould 2002, 59). Gould in his book states that religion deals with the ethical topics concerning what "should be", while the scientific enterprise is engaged in the search for the objective "is" of the natural world. We will not discuss here the classic philosophical issue of so-called is/ought divide, and the debates over what has been called the "naturalistic fallacy" (i.e. the deduction of a moral prescription from the simple description of a natural state of affairs) ${ }^{2}$. But it is worthwhile to highlight here that also Karl Popper, in his lecture, deals with the relation between descriptive and normative judgements. In his case, the object is the relative weight to be assigned to the two different categories:

There have, of course, been people who dogmatically asserted that there is nothing beyond the scope of science and accordingly that such statements as "He ought to do this" are not statements at all but form a meaningless jumble of words [...]. And their insistence on the lack of meaning of the ought-sentences

1 This term appears as the title of one of Gould's monthly essays in Natural History: "Nonoverlapping Magisteria” (Gould 1997). This essay has successively been included in Gould (2011 [1998]).

2 Gould devotes to this topic a long note that goes from page 55 to page 57. 
seems to mean only that the ought-sentences are not of a scientific character. In fact we can simply say that these people use "meaningless" as a synonym for "non-scientific", so that their whole theory can also be expressed in the words "Ought-sentences are non-scientific", which is exactly what I maintain here. (Popper 2008, 44)

Popper affirms that scientific answers are always descriptive in nature (Popper 2008, 44). He adds that science is able to describe human behavior too (Popper 2008, 45). But he thinks as well that a moral decision "cannot be derived from any scientific statement” (Popper 2008, 45). Which kind of moral decision should be taken is a question that neither for Popper nor for Gould falls inside the domain of science; rather, it has to be treated as pertaining to the domain of religion. On these matters-Popper thinks-"religion plays its most significant role in the life of man" (Popper $2008,45)$. In their thought, this represents a crucial difference between the two disciplines. The examples put forth by Gould are indicative of what the two authors have in mind:

Science can say nothing about the morality of morals. That is, the potential discovery by anthropologists that murder, infanticide, genocide, and xenophobia may have characterized many human societies, may have arisen preferentially in certain social situations, and may even be adaptively beneficial in certain contexts, offers no support whatever for the moral proposition that we ought to behave in such a matter". (Gould 2002, 66)

Therefore, according to Gould and Popper each domain has a peculiar role and scope in human life, and each of the two disciplines tries to answer specific questions. To characterize the scientific enterprise Popper, in this lecture, refers to his explication of scientific practice and advancement. According to his epistemology, science proceeds not "by the accumulation of knowledge" but "by way of revolutions", via the amendment and substitution of previous knowledge for the new one (Popper 2008, 42). As a consequence-Popper's thought goes-theories always remain hypotheses, because scientists will never reach the complete certainty of having solved 
a problem (Popper 2008, 42-43). In this regard, it is helpful to quote another passage of his essay:

This does not imply that scientific method is no good, or that the scientific approach to matters must not be taken seriously. Just the opposite. Scientific knowledge is certainly the best we can have, and science does not only make revolutions: it also makes progress. It is perhaps the only field of human activity where there has been steady progress for a considerable time. For the scientist never accepts a revolutionary replacement of his theories without being thoroughly satisfied that the new theories offered are really better than the old ones. (Popper 2008, 42-43)

It is important to highlight this depiction of the scientific enterprise: Popper considers science as probably the sole human activity that has made a stable progress. According to him, this is a peculiarity of the scientific practice. And it seems that for religion the same does not hold. Popper was agnostic (Popper 2008, 49; Artigas 1998, 232), and Gould, in his book, defines himself in the same way (Gould 2002, 8-9). Despite this, Gould defends the position that the two fields of science and religion have the same value, and that both of them are equally necessary to conduct a genuinely human life. Regarding how the two authors conceive the term "religion", both Popper and Gould associate it with ethics, or morality. But there is more to it. Indeed, for Gould religion cannot be totally reduced to moral principles. As we have already noted, according to him religion is, in addition, the field of inquiry that investigates the great questions concerning meaning and the final, ultimate aims. Human beings are called to search for the meaning of their lives, their own personal aims, and the morality of their actions. And each man has to conduct this quest within himself (Gould 2002, 177, 197, 204). The one depicted here is actually a very broad way of conceiving religion, as Gould himself admits:

This magisterium of ethical discussion and search for meaning includes several disciplines traditionally grouped under the humanities-much of philosophy, and part of literature and history, for example. But human societies have usually 
centered the discourse of this magisterium upon an institution called "religion" (and manifesting, under this single name, an astonishing diversity of approaches, including all possible beliefs about the nature, or existence for that matter, of divine power; and all possible attitudes to freedom of discussion vs. obedience to unchangeable texts or doctrines). (Gould 2002, 55-57)

Karl Popper defines religion in a similar way:

I shall, however, maintain in what follows that we must extend the term "religion" even further than is usually done. If you call a man religious because he adheres to any of these different doctrines, then I maintain that we may also have to call him religious even if he does not adhere to any of the different recognized religions, provided that he has some faith which furnishes him with replies to those questions of practical life to which the various religions mentioned provide an answer for those who believe in them. Now of what kind are these questions? I maintain that they are fundamentally questions about the way we ought to act, about what we ought to aim at in this life, for ourselves as well as for mankind as a whole. (Popper 2008, 44)

After defining religion in this way, Gould is careful in adding that, obviously, atheists can and do behave according to ethical principles. But from this statement, it then follows that an atheist does not seem to be ruled out of this broad Gouldian characterization of religion ${ }^{3}$ :

I most emphatically do not argue that ethical people must validate their standards by overt appeals to religion-for we give several names to the moral discourse of this necessary magisterium, and we all know that atheists can live in the most firmly principled manner, while hypocrites can wrap themselves in any flag, including (most prominently) the banners of God and country. But I do reiterate that religion has occupied the center of this magisterium in the traditions of most cultures. (Gould 2002, 57)

3 Harold Allen Orr has noted this in his review of Rocks of Ages for the Boston Review (Orr 1999). 
On this point Popper is even more explicit. He states that it is not possible to depict a clear contradistinction between religious and non-religious people, and in so saying he wants to overcome what is, according to him, the false dichotomy of "religion versus irreligion":

I believe this more particularly in the case of those atheists who claimed with so much emphasis that they did not believe in any religion whatever: I maintain that these people were undoubtedly religious in precisely the same sense in which we attribute the possession of religion to those who believe in the many different creeds [...]. My thesis is that although there may be degrees of faith, although faith may be very strong in some and rather weak in others, there is probably no man who is entirely without it. (Popper 2008, 45)

The problem with beliefs, according to Popper, lies elsewhere. In his viewpoint, beliefs (religions) exist that are human or inhuman. And the difference between these two typologies is of a moral kind. That is, to appreciate or to devalue the "humanitarian idea of helping those who suffer" (Popper 2008, 46). This idea represents the grounding basis of Popperian ethics: it is necessary to lessen the suffering. Furthermore, science itself, as interpreted by this philosopher, has an ethical grounding (Artigas 1998). Indeed, here Popper states that even "the scientific devotion towards truth is itself a religious attitude" (Popper 2008, 47) . Generally, in reading his text it seems that ethics is interpreted by him as a very broad kind of religiosity. He maintains that inhuman religions that lead to intolerance cannot be permitted, because they severely harm humankind. Popper characterizes inhuman religions as follows: "I have of course, the various brands of totalitarianism and racialism in mind. These are movements which with fervent belief try to destroy the greatest achievement of Christianity-the belief that we are all brethren; that all the differences between us are ultimately not very important at all; the belief, in short, in the unity of mankind" (Popper 2008, 46). In the same spirit, according to Gould religion is something that has to do with

4 And he adds that this "is the attitude of serving and making sacrifices for an aim beyond ourselves. It is not only Christians who have been martyrs. There have been martyrs of science" (Popper 2008, 47). 
the unity of humankind: "I will [...] construe as fundamentally religious (literally, binding us together) all moral discourse on principles that might activate the ideal of universal fellowship among people" (Gould 2002, 62).

Summing up, for both Gould and Popper religion can be characterized as an ethics, or a morality, for the human being, and as the enterprise that deals with the search for ultimate meanings. The discussions and decisions over the duties towards other human beings-and more generally over how to behave with the living and the nonliving world as well-are not, according to them, the subject-matter of science; they pertain instead to religion. Popper thus states that there cannot be any interference between science and religion (Popper 2008, 43). And Gould affirms-and this is a crucial statement to understand his proposal-that "facts and explanations developed under the magisterium of science cannot validate (or deny) the precepts of religion" (Gould 2002, 215).

\section{Some Critiques of Gould's NOMA}

The reflections of Gould and Popper could appear, at first glance, to be able to differentiate effectively the domains of science and religion. But on a closer inspection, several troublesome issues appear. If, on the one hand, their proposal seems to be effective in distinguishing the "factual" from the "moral", because it tries to be respectful of the already mentioned is/ ought divide, on the other it is exposed to several lines of criticism. Indeed, since the publication of Gould's book, many critiques of his NOMA principle have been put forth. We will briefly review some of them, in order to have a clearer idea of what is at stake here. These critiques have been addressed to Gould but, because of the striking similarity we have detected between Popper and Gould on science and religion, the criticisms made in the case of the latter can, in our opinion, apply to the former as well.

One of the most radical critiques we have encountered is, without any doubt, the one formulated by biologist and philosopher Massimo Pigliucci. According to him, the NOMA model does not work for the simple fact that the magisterium of religion is "empty" (Pigliucci 2014, 167). He sees 
religion as "consist[ing] of a mixture of superstition, mythology, and folk understanding" (Pigliucci 2014, 164) . And, moving from this point, he then adds that the field of ethics can be tackled effectively by philosophy (i.e. moral philosophy): "Religion has no authority when it comes to an understanding of the natural world, as Gould himself of course stressed. But it has also no authority in the realm of morality, contra Gould's somewhat naive and/or Pollyannaish view" (Pigliucci 2014, 167). If religion consists only in what Gould and Popper allege, then this trenchant critique is effective: in principle, an informed philosophical approach to topics such as morality and meaning could easily replace it. Moving to more moderate objections, the most widespread affirms, in a nutshell, that the definition that Gould makes of religion turns out to be both too vague and too restrictive regarding how it should (or should not) be conceived. This is because religion is usually considered as consisting of much more than what Gould indicates. The clearest instance of this is the fact that religions usually formulate some explicit ontological claims - or truth claims-regarding reality (Ruse 2010, $232 ; 2015,120)$. For present purposes, we can now leave aside the respective differences between disparate religions, and recall one truth claim that is basic-crucial indeed-for the three Abrahamic monotheisms (Christianity, Judaism, Islam) and for many other religions as well: God exists. Even the viability of a discussion on this statement turns out to be problematic if contextualized inside Gould's proposal ${ }^{6}$. Furthermore, and closely related to it, the decoupling of this religious truth claim from the establishment

5 Pigliucci, in commenting on the connection between folk wisdom and morality admits that "folk wisdom does go a good way toward helping us with ethical questions, and if religions are, to a point, a distillation of folk wisdom then they can certainly be useful in this respect". But according to him "the problem [...] is the alleged source of moral authority claimed by religions: one or more supernatural entities who simply dictate what is right or wrong" (Pigliucci 2014, 165).

6 At the beginning of his interview with Edward Zerin, Popper too decouples religion from the issue of God's existence: "Although I am not a Jew by religion, I have come to the conclusion that there is great wisdom in the Jewish commandment 'not to take the name of God in vain'. My objection to organized religion is that it tends to use the name of God in vain. I don't know whether God exists or not. We may know how little we know, but this must not be turned or twisted into a positive knowledge of the existence of an unfathomable secret" (Popper 2008, 48-49). 
of a morality and a meaning for life would generally be seen-from the religious viewpoint-as equally problematic. These two points have been clearly encapsulated by philosopher of science Ernan McMullin while commenting on Gould's NOMA:

The restriction of religion to the realm of meaning and moral value leaves the status of God as an existent being in doubt. But unless God is, unless God is somehow involved in human affairs, it is not at all clear how religion can effectively serve the roles of conveyor of ultimate meaning and arbiter of moral value that Gould assigns to it. Perhaps a naturalized religion? (McMullin 2011, 84 ; italics in original)

Biologist and theologian Denis Alexander, in an essay on "The Implications of Evolutionary Biology for Religious Belief", follows this line of critique as well. According to him, many of the truth claims regarding reality that religious people are interested in asserting and defending are of an ethical kind, thus rendering, in this case, the distinction of the "is" from the "ought" not that clear-cut:

The partitioning of facts to the world of science and values to the world of religion is inconsistent with religious claims. Most religious believers would maintain that they hold to facts about the world, such as the fact that the human psyche is sinful or that rape is wrong. These are not scientific facts but, arguably, facts nonetheless. The neat facts/values partition does not therefore work in practice. (Alexander 2013, 184)

But the scope of the truth claims offered by religions is wider than that concerning moral issues, as already noted by mentioning the question of God's existence. Another well-known critic of Gould, philosopher Daniel Dennett, recalls the discontent that arose from both sides of the divide after the publication of Gould's book in his Breaking the Spell: Religion as a Natural Phenomenon (2006). In a short list of what-far from endorsing any of them-he defines as the "religious claims to factual truth and understanding of the natural world" (2006, 30), he lists the claim of God being the creator of the entire universe, the occurrence of miracles, and that 
God is supposed to listen to prayers. Furthermore, he recalls the critique moved by the secularists too. According to them, Gould's scheme "granted too much authority to religion in matters of ethics and meaning" (2006, 30). As a result, in the end both advocates and critics of religion turn out to be dissatisfied with the depiction of this magisterium as put forth by Gould. In the words of Karl Giberson and Mariano Artigas, "supporters of religion find that the space Gould allocates to religion is simply too small for their religion to fit. On the other hand, opponents of religion want scientific warrant to challenge the truth-claims of religion" (Giberson and Artigas 2007, 80).

To sum up, it seems as if the neat independence that Gould advocates for his two magisteria is too simplistic a vision of what is actually a more complicated and intertwined relation. Far from promoting some sort of fusion of the two fields, or on the contrary a defense of a model of intrinsic and inevitable warfare, what we want to point to here-with this overview of some critiques to Gould-is that the relation between science and religion cannot be conceived in such an unproblematic way. Some tough and nuanced philosophical work is awaiting those who are interested in this challenging topic. This philosophical work has to tackle claims that come both from the magisterium of science and the magisterium of religion, and has to make sense of them. In this regard, the critics of Gould sustain that the NOMA theory is not able to fulfil this task. In the next section we offer another concrete example of this inability.

\section{One More Problem for Gould's NOMA}

In Rocks of Ages Gould is very effective in criticizing those fundamentalist North American creationists that oppose and deny some aspects of contemporary science, and Darwin's theory in particular, on the basis of a literalist reading of the Bible, and who historically have attemptedwithout success - to introduce their ideas "into science curricula of public schools" (Gould 2002, 126). Their stance clearly flies in the face of Gould's theory of NOMA (Gould 2002, 93), and, according to Barbour, falls inside 
the conflict option (Barbour 1998, 82-84) ${ }^{7}$. But then Gould-as pointed out many times by his critics-goes too far, and interprets as a "violation of NOMA" (Gould 2002, 93) the acceptance or endorsement of some elements of religion that are usually held as crucial by theologians and believers. As a clear example of this, we can consider a topic that Gould recalls in Rocks of Ages, and that he tackles at length elsewhere, in other popular books (Gould 2002, 179-180, 206; 1989; 1996): the positioning of man in the wider context of the evolutionary scenario, in the light of the contingency of evolution. This concept-evolutionary contingency-conveys the idea that natural history is in general unpredictable, and that the appearance of our species, from the evolutionary standpoint, has been an "unexpected" event (Pievani 2009; 2011). In Gould's words, we are "a "thing so small” in a vast universe, a wildly improbable evolutionary event, and not the nub of universal purpose" (Gould 2002, 206). But given this-as philosopher of biology Michael Ruse has underlined in commenting on Gould's book-the theologians or, more generally, the men of faith must try to harmonize this recognition, if possible, with a fundamental theological concept, that of man being "made in the image of God", of his being wanted, and expected by Him:

Crucially, it is part of Judaeo-Christian theology that humans are not simply animals like any other, nor is our existence on this earth simply a matter of contingency. We are made in the image of God (whatever that might mean) and, although the universe may not exist for our special benefit, we humans

\footnotetext{
Gould, interestingly, refuses to locate this phenomenon inside the warfare stance, and offers another interpretation of it by referring to his NOMA theory: "The forceful and persistent attempt by young-earth creationists to insinuate their partisan and minority theological dogma into the science curricula of American public schools cannot be read, in any legitimate way, as an episode in any supposedly general warfare between science and religion. If the issue must be dichotomized at all, the two sides might be characterized as supporters versus opponents of NOMA" (Gould 2002, 128). This judgement can be better understood in the light of Gould's distinction between the particular kind of creationism criticized by him and religion as generally considered. This distinction has been suggestively described, in biblical terms, by Patricia H. Kelley as "Gould's winnowing fork": Gould "winnow[ed] the chaff of creationism from the wheat of religion" (Kelley 2009, 173).
} 
do have a rather special place in the scheme of things [...]. I simply do not see how the Jew or Christian can or should leave matters untouched at this point, passively accepting the science as given and gutting the religion of absolutely central content: evolution is contingent and hence we humans cannot make claim to special status. (Ruse 1999)

This issue is a thorny one, and lies at the forefront of the interdisciplinary dialogue. But again, Gould's proposal turns out to be, in this particular context also, inadequate to handle it. As philosopher Mikael Stenmark has underscored, an inconsistency emerges in Gould's assessment of this topic:

What is puzzling is how Gould as a scientist could maintain that a religious belief in the ultimate meaning of human life ought to be rejected and at the same time proclaim that 'facts and explanations developed under the magisterium of science cannot validate (or deny) the precepts of religion'. These claims are not compatible (Stenmark 2004a, 188; italics in original).

A different solution has to be searched for in order to disentangle this issue. From the theological viewpoint, man has got a special status, and his appearance has been decided by God. But simply dismissing these statements in the light of our best evolutionary account of how we came about would amputate Christian theology (and many other religions as well) of a fundamental component: that is, of one of those "factual claims" (Ruse 2015, 112) that religions formulate and defend. Some epistemological mediation should be attempted. To be sure, this should be done without ignoring the actuality of the contingency of evolution. But at the same time, the task should be to try to offer positive arguments, drawing from metaphysics and theology (Stenmark 2004a, 191), on the effectiveness of a supposed creator in obtaining what he wants from a contingent evolutionary path ${ }^{8}$.

8 For an excellent instance of this see McMullin (1998), and see also the comment on this work by Stoeger (2013). On this topic see also Stenmark (2004a, 189-191). 


\section{Gould's NOMA inside Barbour's Scheme}

It might be useful at this point to consider how Gould's viewpoint can be located inside Barbour's scheme. Patricia Kelley, in analyzing his theoretical proposal, has shown that two of the four options can promptly be excluded (Kelley 2009, 171-188). In fact, Gould himself criticizes them at length in his book. As far as his dismissal of the conflict thesis is concerned, we have already remarked that this is a position shared by both Gould and Popper. Indeed, Gould devotes a part of Rocks of Ages to summarizing and criticizing the warfare view. In so doing, he recalls the origins of what is, in his evaluation, a "false model" (Gould 2002, 111) that depicts the relation between science and religion as a "warfare between two inexorably opposed forces vying for the same turf" (Gould 2002, 102): it harks back to the nineteenth century, and more precisely to the publication of Andrew Dickson White's A History of the Warfare of Science with Theology in Christendom, and of John William Draper's History of the Conflict Between Religion and Science (Gould 2002, 99-110, 118-124). Gould defends his dismissal of this model even in the face of the fact that historically-as he himself reminds us-"overt struggle" actually occurred (Gould 2002, 103). In addition, Gould dismisses the fourth option too, the one labeled integration. He calls this attitude "syncretic" (Gould 2002, 212; Kelley 2009, 176), and considers as a pertinent example of it a congress on interdisciplinary issues on the occasion of which-according to him-an attempt of this kind was undertaken (Gould 2002, 208-222). Amongst the proposals offered by the syncretic school, Gould criticizes and dismisses those versions of the argument from design for God's existence that take as their starting point the alleged "fine-tuning" of the physical constants of the universe that permit the existence of intelligent life, and from this try to infer a supernatural fine-tuner (Gould 2002, 218-220; Kelley 2009, 176-177) ${ }^{9}$. By referring to Barbour's fourfold

9 It is interesting to note that Karl Popper too in his lecture criticizes those who think that the developments of science support or confirm particular religious claims: "We hear statements, made by the defenders of religion as well as by certain scientists, to the effect that modern scientific developments can be interpreted as supporting religious faith rather than as questioning it; and when I speak about the nineteenth-century problem 
typology as applied by Kelley on Gould's theorization, we can place his proposal inside the independence stance (Kelley 2009, 175; Ruse 2015, 232). Moreover, Kelley also notes that-due to his frequent call for a deep dialogue between the two magisteria-Gould's overall proposal "appears to also share some aspects of Barbour's third category” (Kelley 2009, 175). Indeed, in putting his thought to paper Gould repeatedly seems to try to move beyond the idea of a complete independence of the two domains. In various passages of his book Gould states that science and religion, without trespassing the respective borders, should nonetheless try to engage in a conversation: "NOMA seeks no false fusion, but urges two distinct sides to stay on their own turf, develop their best solutions to designated parts of life's totality, and, above all, to keep talking to each other in mutual respect, and with an optimistic forecast about the value of reciprocal enlightenment" (Gould 2002, 211; and see also 5, 92, 148). Furthermore, in characterizing the two magisteria Gould maintains that they encompass two typical human attitudes. Science-as already recalled above-is by him depicted as the quest for an objective knowledge of the natural world. And religion-in Gould's interpretation of it-is the quest for the meaning of each and every human life, as well as for the moral principles that can guide and enlighten human actions (Gould 2002, 175). For this reason, according to Gould the knowledge earned by each magisterium should integrate in the personal life of every man:

All human beings must pay at least rudimentary attention to both magisteria of religion and science, whatever we choose to name these domains of ethical and factual inquiry. Mere existence may be sustained by the minimal concern caricatured above. But real success-at least in the old-fashioned sense of genuine stature-requires serious engagement with the deep and difficult issues

of the tension between religion and science I do not wish to imply, as some may think, that in the twentieth century this problem has disappeared because it now turns out that science supports religious belief. My point is entirely different. Supposing that science is accepted as supporting religion-then if at a certain stage of its development it turns out that it agrees with some religious doctrines and we adopt them for that reason, we would also have to accept the refutation of those doctrines by science, if at some other stage of its development science should arrive at a different opinion” (Popper 2008, 42). 
of both magisteria. The magisteria will not fuse; so each of us must integrate these distinct components into a coherent view of life. If we succeed, we gain something truly "more precious that rubies", and dignified by one of the most beautiful words in any language: wisdom. (Gould 2002, 58)

Doubts remain, however, on how these two magisteria-when encapsulated in Gould's theory-could effectively integrate inside each thinking man, given the many tensions and epistemological dead ends that, following some of his most authoritative critics, we have recalled in this essay. It is true that Gould sees himself as an advocate of the dialogue, envisioning a theory of NOMA always undertaking a "tough-minded and insistent search" for it (Gould 2002, 221). But the critique that can be extended to him at this point is that, given the way in which his theory is articulated, and the theoretical restrictions imposed by it on religion, this alleged dialogue will in the end turn out to be sterile, and-as we have shown with the case of evolutionary contingency-incapable of tackling effectively some core problematic issues.

\section{Conclusion}

In this paper we have offered a brief comparison of the thought of Stephen Jay Gould and Karl Popper on science and religion. On this topic, they share essentially the same position. This exposes Popper's ideas to the same lines of criticism that have been extended to Gould, and that we have recalled in section two and three. To end with a positive note, we want to stress the significance of Gould's and Popper's efforts in trying to make sense of diverse human enterprises without criticizing or even dismissing the one in order to fully value the other. In an era when polarizations and false dichotomies are sometimes regarded as easy ways to solve complex issues, their effort has to be met with gratitude. Unfortunately, Gould's proposal turns out in the end to be too simplistic, and the criticisms of it are generally well posited and pertinent. We nonetheless believe-and in this we agree with Gould-that the conflict and the integration stances are not going to lead to significant results in interdisciplinary issues of this 
kind, and must be avoided. In order to achieve a fruitful exchange between science and religion, we should seriously take into consideration the two other emplacements identified by Barbour, and value them: the one of independence and the one of dialogue. In this regard, as we have recalled in section four, Gould's framework presents aspects typical of both the independence and the dialogue positions. It could be useful, in our view, to move from this emplacement-independence with dialogue-and try to structure this theoretical position in a way that is capable of overcoming the epistemological limits and standoffs that emerge from Gould's and Popper's proposals. We believe that the dialogue between science and religion must start by preserving and safeguarding their independence. The challenge that lies ahead is to do that in a way that is respectful of both science and religion, of their respective methodologies as well as of their specific contents, in order to tackle more effectively the thorny issues that lie at their borderlands.

\section{References}

Alexander, D. R. 2013. “The Implications of Evolutionary Biology for Religious Belief." In The Philosophy of Biology: A Companion for Educators, edited by K. Kampourakis, 179-204. Dordrecht: Springer.

Artigas, M. 1979. Karl Popper. Búsqueda sin término. Madrid: Magisterio Español.

-. 1998. "The Ethical Roots of Karl Popper's Epistemology." Acta Philosophica 7:

197-233.

-. 1999. The Ethical Nature of Karl Popper's Theory of Knowledge: Including Popper's

Unpublished Comments on Bartley and Critical Rationalism, edited by I. Slade.

Bern: Peter Lang.

-. 2002. "Popper Biography and Something More." Philosophy of the Social Sciences 32: 387-401.

-. 2005. "El cordero y el león. Ciencia y religion en Stephen Jay Gould." Scripta Theologica 37: 141-158.

Barbour, I. G. 1998. Religion and Science: Historical and Contemporary Issues. A Revised and Expanded Edition of Religion in an Age of Science. London: SCM Press LTD. Dennett, D. C. 2006. Breaking the Spell: Religion as a Natural Phenomenon. New York: Viking. 
Giberson, K., and M. Artigas. 2007. Oracles of Science: Celebrity Scientists versus God and Religion. New York: Oxford University Press.

Gould, S. J. 1989. Wonderful Life: The Burgess Shale and the Nature of History. Cambridge MA: Harvard University Press.

-. 1996. Full House: The Spread of Excellence from Plato to Darwin. New York: Harmony Book.

-. 1997. "Nonoverlapping Magisteria." Natural History 106:16-22.

-. 2002 [1999]. Rocks of Ages: Science and Religion in the Fullness of Life. New York: Ballantine Books.

-. 2011 [1998]. Leonardo's Mountain of Clams and the Diet of Worms: Essays on Natural History. New York: Harmony Books.

Kelley, Patricia H. 2009. “Stephen Jay Gould’s Winnowing Fork: Science, Religion, and Creationism." In Stephen Jay Gould: Reflections on His View of Life, edited by W. D. Allmon, P. H. Kelley, and R. M. Ross, 171-188. New York: Oxford University Press.

McMullin, Ernan. 1998. “Cosmic Purpose and the Contingency of Human Evolution.” Theology Today 55: 389-414.

-. 2011. "Varieties of Methodological Naturalism.” In The Nature of Nature: Examining the Role of Naturalism in Science, edited by B. L. Gordon, and W. A. Dembski, 82-94. Wilmington DE: Isi Books.

Murray, M. J. 2009. “Science and Religion in Constructive Engagement.” In Analytic Theology: New Essays in the Philosophy of Theology, edited by O. D. Crisp, and M. C. Rea, 233-247. New York: Oxford University Press.

Orr, H. A. 1999. “Gould on God: Can Religion and Science Be Happily Reconciled?” Boston Review. Accessed May 17, 2016. http://new.bostonreview.net/BR24.5/ orr.html.

Peters, T. 1998. “Science and Theology: Toward Consonance.” In Science and Theology: The New Consonance, edited by T. Peters, 11-39. Boulder CO: Westview Press. Pievani, T. 2009. “The World after Charles R. Darwin: Continuity, Unity in Diversity, Contingency.” Rendiconti Lincei: Scienze Fisiche e Naturali 20: 355-361.

-. 2011. La vita inaspettata. Il fascino di un'evoluzione che non ci aveva previsto. Milano: Raffaello Cortina Editore.

Pigliucci, M. 2014. “5 Questions on Science \& Religion.” In Science and Religion: 5 Questions, edited by G. D. Caruso, 163-169. Copenhagen: Automatic Press / VIP. Popper, K. 2008. After the Open Society: Selected Social and Political Writings, edited by J. Shearmur, and P. N. Turner. New York: Routledge.

Ruse, M. 1999. “Review of Stephen Jay Gould's “Rocks of Ages.” Accessed May 17, 2016. http://www.metanexus.net/book-review/review-stephen-jay-goulds-rocks-ages. 
-. 2010. "Atheism, Naturalism and Science: Three in One?" In The Cambridge Companion to Science and Religion, edited by P. Harrison, 229-243. New York: Cambridge University Press.

-. 2015. Atheism: What Everyone Needs to Know ${ }^{\oplus}$. New York: Oxford University Press. Stenmark, M. 2004. “Contemporary Darwinism and Religion.” In Darwinian Heresies, edited by A. Lustig, R. J. Richards, and M. Ruse, 173-191. New York: Cambridge University Press.

-. 2004. How to Relate Science and Religion: A Multidimensional Model. Grand Rapids MI: William B. Eerdmans Publishing Company.

Stoeger, W. R. 2013. "Ernan McMullin on Contingency, Cosmic Purpose, and the Atemporality of the Creator." Zygon: Journal of Religion and Science 48: 329-337. 